\title{
Action Mechanism and Practical Experience of City Parks from the Perspective of Health Promotion - Take Hangzhou West Lake City Parks as an Example
}

\section{Research}

Keywords:

Posted Date: November 4th, 2020

DOl: https://doi.org/10.21203/rs.3.rs-76710/v2

License: (c) (1) This work is licensed under a Creative Commons Attribution 4.0 International License. Read Full License 


\section{Abstract}

The authors have requested that this preprint be withdrawn due to erroneous posting.

\section{Full Text}

The authors have withdrawn this preprint from Research Square. 